A grant has been received also from the International Cancer Research Foundation, an organisation established last year in Philadelphia by Mr. William H. Donner and endowed by him with a sum of 2,000,000 dollars. Although its administrative headquarters are situated in America, the Foundation is world-wide in its scope. The income of the fund is to be applied to assist research into the causes, prevention, control, relief and cure of cancer, and this income is to be so distributed that not less than 35 per cent nor more than 50 per cent is to be allotted in countries other than the United States. The trustees have awarded a sum of $£ 1,000$ a year for a period of two years to the Cancer Hospital Research Institute in support of investigations into factors which underlie the origin of malignant growths. This sum will provide two research studentships, to one of which Mr. G. A. D. Haslewood has been appointed. The two research students will undertake the investigations of special problems in connexion with the general scheme of research now in progress at the Cancer Hospital.

\section{Protection against Lightning}

WE welcome the handbook entitled "Code for Protection against Lightning", a revised edition of which has just been published (U.S. Government Printing Office, Washington, 1933, 15 cents). The number of fatalities from lightning in the United States is insignificant in comparison with the 100,000 annually from all other accidental causes. But the suddenness with which the flash happens, and the apparent impossibility of telling where it may strike next, may well frighten the bravest. Directions are therefore given for personal conduct during thunderstorms. If it is necessary to be out of doors, it is desirable to keep away from small sheds in exposed localities, isolated trees, wire fences, hilltops and wide open spaces. Shelter can be sought in a cave, a depression in the ground, a deep valley, at the foot of a steep or overhung cliff or in a grove of trees. Best of all is to stay indoors and keep away from fireplaces, stoves and all other large metal objects. Modern buildings are safe because of the protective effects of the metal used in constructing them and the metal piping on the exterior walls. The rules for erecting liglitning conductors are now practically standardised. An approved protector should be placed as near as practicable to the point of entrance of an aerial telephone wire into a building. Metal radio masts should be bonded to the nearest lightning conductor. Wooden radio masts which extend six feet or so above the highest parts of the building should be provided with a connexion to earth. In an appendix, various kinds of lightning phenomena are described and modern theories are explained. A very instructive map is given showing the average number of days on which thunderstorms occur at many stations in the United States and Canada. There are very few thunderstorms on the Pacific Coast but at Tampa in Florida the number of days per annum on which thunderstorms occur is 94 .

\section{Archæological Exploration in Oaxaca, Mexico}

RECENT reports received by Science Service. Washington, D.C., from Miss Emma Reh, who is engaged in archæological exploration in Mexico, point to the possibility of further discoveries bearing on the problem of the position of Mixtec culture and the area now known as the province of Oaxaca as a connecting link between the Mayan culture to the south and Mexican culture to the north. It will be remembered that this was the problem on which S. Alfonso Caso was engaged at the time he discovered the treasure tomb of Monte Alban a year ago. Miss Reh has recently examined the sites of two ruined cities in the mountainous Mixteca area, Teposcolula and Hualmelulpan, situated eighteen miles apart, neither of which had previously been recorded on the official archæological map of Mexico. Hualmelulpan was an important centre which once dominated the road from north to south. In the inner of two pyramids, built one over the other, Indians have found a number of sculptures and idols. Among them Miss Reh reports a sculptured slab which bears the date "Thirteen Stone Knife" in the Mayan numeral system, constituting an important link with the Mayan culture to the south. Among other material is a human figure more than six feet high carved from stone, which shows a snarling mouth armed with formidable fangs. This may be the ancient Mixtec deity Tepeyolotl, "Heart of the Mountains", often represented as a tiger. Pottery heads found on the mounds and terraces range in series extending from 'Mixtecan' to 'archaic'.

Accommodation for Paying Patients at Voluntary Hospitals

THERE is a growing demand for nursing accommodation for those who, unable to pay the charges of a nursing home, desire better accommodation or more privacy than is provided in ordinary hospital wards and are willing to pay for it. King Edward's Hospital Fund for London has therefore issued a list of the 'pay beds' at hospitals making returns to the King's Fund, with particulars of the accommodation and of the normal weekly charge. The pamphlet may be obtained from the Fund, 7 Walbrook, E.C.4, price $3 d$. including postage.

\section{Health of the British Army during 193r}

IN the report on the health of the army for the year 1931 (H.M. Stationery Office. 2s. 6d. net), the Director-General, Lieut.-Gen. Faweus, states that the health of all ranks both at home and abroad was satisfactory. With an average strength of 181,508, the principal causes of admission to hospital were influenza, malaria, and venereal diseases, with 8,324 , 7,191 , and 5,865 cases respectively. Tonsilitis accounts for 5,752 cases, a decrease over the previous year. Dysentery has increased somewhat. Venereal diseases have shown an almost steady fall during the last ten years, from 70 per 1,000 strength in 1922 to 33 per 1,000 in 1931 .

\section{Californian Earthquake of March Io}

LATFR accounts of this earthquake show that, though stronger than the Santa Barbara earthquake 